\title{
ANALISIS FAKTOR-FAKTOR YANG BERPENGARUH TERHADAP PENCEGAHAN FRAUD DI DALAM PROSES PENGADAAN BARANG DAN JASA
}

\author{
Yarry Septia Larasati, Dadang Sadeli, Surtikanti \\ Magister Akuntansi Universitas Pancasila \\ E-mail: y4rry s@yahoo.co.id
}

\begin{abstract}
The aim of this study is to obtain empirical data about the influence of internal control role, whistleblowing system, and good governance both partially and simultaneously to the prevention of fraud. This research involving 53 respondents in the scope of Directorate General of Marine Spatial Management Ministry of Marine Affairs and Fisheries, Republic of Indonesia. This research apply a survey by questionnaire as research instrument while methods used to process and analyze data on research are descriptive analysis and analysis of multiple regression. The results show that internal control role, whistleblowing system, and good governance have significant effects against fraud prevention partially, with count $t$ larger than $t$ table and positive value of regression. Furthermore, internal control role, whistleblowing system and good governance effect simultaneously to the prevention of fraud with the count $f$ larger than $f$ table. From this study, it can be concluded that internal control role, whistleblowing system and good governance whether partially and simultaneously effect prevention of fraud.
\end{abstract}

Keywords: Internal Control, Whistleblowing System, Good Governance, Prevention of Fraud

\section{PENDAHULUAN}

Pesatnya perkembangan

perekonomian di dunia tidak hanya memberikan banyak manfaat bagi masyarakat, tetapi juga diiringi dengan semakin berkembangnya fraud atau biasa dikenal dengan istilah kecurangan. Seperti halnya di Amerika Serikat, kasus Enron menjadi contoh manipulasi laporan keuangan dengan mencatat keuntungan sebesar US\$600 juta, sedangkan pada saat itu Enron mengalami kerugian. Selain itu terdapat juga kasus WorldCom, Global Crossing dan Adelphia yang jatuh akibat skandal kecurangan (fraud) dalam bentuk pencurian aset, kejahatan komputer, korupsi maupun manipulasi pelaporan keuangan (Yenny, 2014). Begitu juga di Indonesia, pada tahun 2001 tercatat skandal keuangan di perusahaan publik yang melibatkan manipulasi laporan keuangan oleh PT Lippo Tbk dan PT Kimia Farma Tbk. PT Kimia Farma memanipulasi laporan keuangan dengan cara melaporkan adanya laba bersih sebesar
Rp132 milyar padahal seharusnya hanya sebesar Rp99,56 miliar, atau lebih rendah sebesar Rp32,6 milyar, atau 24,7\% dari laba awal yang dilaporkan (Kencana, Rizki Wastu. Kasus Kimia Farma. Kompasiana, 2012. Web. $20 \quad$ Januari 2016. http://kompasiana.com/kasus-kimia-farmaetika-bisnis).

Menurut Indonesia Procurement Watch (IPW), dari 385 kasus korupsi yang ditangani Komisi Pemberantasan Korupsi (KPK), 70 persen diantaranya merupakan kasus pengadaan barang dan jasa. Pengadaan oleh pemerintah yang dilakukan secara konvensional dinilai masih memiliki tiga kelemahan, yaitu: transparansi, inefisiensi, dan ketidaksesuaian fungsi pengadaan (LKPP, 2010:19). Hal ini membuktikan bahwa terdapat kesalahan dan adanya konflik kepentingan dalam suatu organisasi.

Upaya pencegahan fraud nampaknya dipengaruhi oleh berbagai faktor antara lain adanya peran pengendalian internal, whistleblowing system, good corporate 
governance dan lain-lain. Pengendalian internal adalah suatu proses yang dipengaruhi oleh beberapa pihak yang mempunyai peranan penting dalam suatu perusahaan seperti dewan direksi, manajemen dan personel lain yang dirancang untuk menyediakan jaminan memadai mengenai prestasi dari sasaran kinerja dalam (1) efektivitas dan efisiensi operasional (2) keandalan pelaporan keuangan dan (3) pemenuhan dari ketentuan hukum yang bisa diterapkan dan regulasi (IAPI,2011:319). Pengendalian internal berperan penting dalam mencegah terjadinya dan mendeteksi fraud serta untuk melindungi sumber daya organisasi baik yang berwujud maupun tidak berwujud. Jika pengendalian internal dirancang dan dilaksanakan dengan baik dan pegawai melaksanakan tugasnya dengan baik maka pengendalian inetrnal dapat diandalkan dalam melindungi diri dari fraud.

Fraud juga dapat dicegah dengan adanya whistleblowing system. Whistleblowing system merupakan sebuah mekanisme penyampaian pengaduan dugaan tindak pidana korupsi yang telah terjadi atau akan terjadi yang melibatkan pegawai dan orang lain yang berkaitan dengan dugaan tindak pidana korupsi yang dilakukan di dalam organisasi tempatnya bekerja. Indonesia, sebagai negara di Benua Asia merupakan negara dengan budaya kolektif yaitu kehidupan sosial menjadi lebih dominan dalam keseharian dibandingkan dengan kehidupan pribadi. Kondisi budaya yang seperti itu, menjadikan whistleblower system menjadi lebih sulit diterapkan di Indonesia. Padahal whistleblowing system yang efektif akan mendorong partisipasi masyarakat dan karyawan perusahaan untuk lebih berani bertindak dalam mencegah terjadinya kecurangan dan korupsi dengan melaporkannya ke pihak yang dapat menanganinya. Sehingga dengan adanya whistleblowing system ini maka lebih dapat meningkatkan kejujuran dan keterbukaan.

Selain itu good corporate governance nampaknya juga berpengaruh dalam mencegah terjadinya fraud. Praktik yang tidak sehat dalam tata kelola perusahaan memungkinkan terjadi fraud yang sulit terdeteksi oleh pihak pemangku kepentingan. Corporate governance merupakan alat untuk menjamin direksi dan manajer (insider) agar bertindak yang terbaik untuk kepentingan investor luar (kreditur atau shareholder) (Jackson, 2009). Badan pengelola pasar modal di banyak negara menyatakan penerapan tata kelola perusahaan di perusahaan-perusahaan publik secara baik telah berhasil mencegah praktik kecurangan atas laporan keuangan kepada pihak yang berkepentingan (Sutoyo dan Aldridge, 2005). Fraud juga dapat dicegah jika suatu organisasi memiliki adanya budaya etis. Budaya etis organisasi merupakan suatu pola tingkah laku, kepercayaan yang telah menjadi suatu panutan bagi semua anggota organisasi. Tingkah laku merupakan suatu tingkah laku yang dapat diterima oleh moral dan benar secara hokum. Di dalam suatu budaya organisasi yang etis terdapat adanya suatu komitmen dan lingkungan yang etis pula (Pristiyanti, 2012). Jika suatu organisasi mempunyai budaya etis organisasi yang rendah maka akan mendorong karyawannya untuk melakukan tindakan fraud atau kecurangan, sehingga dapat disimpulkan bahwa semakin baik budaya etis organisasi suatu instansi akan semakin rendah kecenderungan karyawan melakukan fraud atau kecurangan.

Berdasarkan uraian masalah di atas dapat diidentifikasikan bahwa fraud terjadi karena lemahnya pengendalian internal dalam suatu perusahaan meskipun perusahaan tersebut telah memiliki standar dan peraturan, banyak perusahaan yang belum menerapkan konsep corporate governance sehingga perusahaan tersebut 
tidak berjalan sesuai dengan harapan para stakeholder. Masih rendahnya moral yang dimiliki masyarakat dalam kehidupan sosial menyebabkan banyak terjadi perilaku yang menyimpang seperti praktik-praktik yang koruptif. Di sisi lain mayoritas masyarakat bersikap tidak peduli bahkan mendukung fraud karena ketidakpedulian tersebut muncul pada tindakan negosiasi dengan memberikan sejumlah imbalan tertentu.

Tujuan Penelitian ini adalah menganalisis tentang seberapa besar pengaruh peran pengendalian internal, whistleblowing system dan good corporate governance terhadap pencegahan fraud dan menganalisis tentang seberapa besar pengaruh peran pengendalian internal, whistleblowing system, dan good corporate governance secara simultan terhadap pencegahan fraud.

\section{KAJIAN TEORI, KERANGKA PEMIKIRAN DAN HIPOTESIS \\ Teori Fraud Triangle}

Fraud triangle adalah sebuah teori yang dikemukakan oleh Donald R. Cressey setelah melakukan penelitian untuk tesis doktornya pada tahun 1950. Cressey mengungkapkan bahwa ada tiga faktor yang mendukung seseorang melakukan fraud, yaitu masalah keuangan yang harus dirahasiakan (pressure), kesempatan (opportunity) untuk melakukan fraud, dan rasionalisasi (rationalization) dari pelaku.

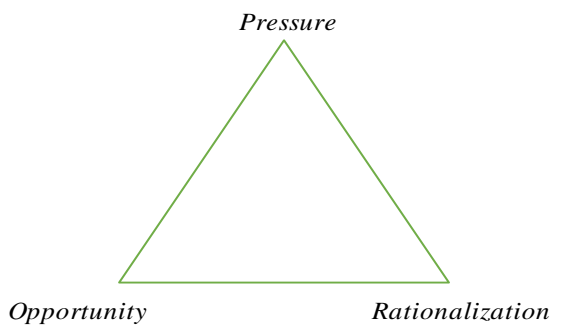

Gambar 1. Fraud Triangle

Sumber: Tuanakotta (2010)
Menurut Tuanakotta (2010: 207-214) faktor seseorang melakukan kecurangan disebabkan oleh:

1. Tekanan (pressure)

2. Kesempatan (opportunity)

3. Pembenaran (rationalization).

\section{Teori GONE}

Menurut Jack Bologne (Simanjuntak 2008: 122), terdapat empat faktor pendorong seseorang melakukan kecurangan, yang disebut dengan teori GONE, yaitu:

a. Greed (keserakahan)

b. Opportunity (kesempatan)

c. Need (kebutuhan)

d. Exposure (pengungkapan)

Faktor Greed dan Need merupakan faktor yang berhubungan dengan individu pelaku kecurangan (disebut faktor individual). Faktor individual berhubungan dengan perilaku yang melekat dari individu itu sendiri. Faktor individu ini berhubungan dengan moralitas untuk melakukan kecurangan. Sedangkan faktor Opportunity dan Exposure merupakan faktor yang berhubungan dengan organisasi sebagai korban perbuatan kecurangan (disebut faktor generik/umum).

\section{Akuntansi Forensik}

Definisi akuntansi forensik menurut Hopwood et al. (2008: 3) yaitu:

"forensic accounting is the
application of investigative and
analytical skills for the purpose of
resolving financial issues in a manner
that meets standards required by
courts of law."

Akuntansi forensik adalah aplikasi keterampilan investigasi dan analitik yang bertujuan untuk menyelesaikan masalahmasalah keuangan melalui cara-cara yang sesuai dengan standar yang ditetapkan oleh pengadilan dan hukum. Sedangkan menurut Tuanakotta (2010: 4) akuntansi forensik adalah penerapan sistem akuntansi dalam 
bidang hukum terutama pada permasalahan kecurangan atau fraud.

Akuntansi forensik adalah aplikasi ilmu akuntansi yang bermanfaat dalam penyelesaian dan pencegahan tindak pidana korupsi. Dengan demikian diperlukan akuntan forensik yang mempunyai keahlian dalam menginvestigasi indikasi adanya korupsi atau tindak penyelewengan lainnya di sebuah perusahaan atau instansi negara. Secara harfiah korupsi merupakan sesuatu yang busuk, jahat dan merusak (Hartanti, 2005: 9). Perbuatan korupsi dalam istilah kriminologi digolongkan kedalam kejahatan white collar crime. Korupsi juga diartikan sebagai penjualan barang-barang milik pemerintah oleh pegawai negeri untuk keuntungan pribadi.

\section{Pengendalian Internal}

Menurut Tunggal (2010: 195) pengendalian internal adalah suatu proses yang dijalankan oleh Dewan Komisaris, Manajemen, dan Personal entitas lain yang didisain untuk memberikan keyakinan memadai tentang pencapaian tiga golongan tujuan berikut: (a) Keandalan pelaporan keuangan (b) Efektivitas dan efisiensi operasi, dan (c) Kepatuhan terhadap hukum dan peraturan yang berlaku. Sedangkan menurut Krismiaji (2010: 218) pengendalian internal (internal control) adalah rencana organisasi dan metode yang digunakan untuk menjaga atau melindungi aktiva, dan menghasilkan informasi yang akurat dan dapat dipercaya.

Jadi dari definisi di atas dapat disimpulkan bahwa pengendalian internal adalah suatu cara sistematis yang dijalankan oleh seluruh pegawai dalam suatu perusahaan yang digunakan untuk melindungi aktiva dan memberikan informasi yang akurat dan memadai dalam mencapai tujuan keandalan laporan keuangan, efektivitas dan efisiensi operasi, dan kepatuhan terhadap hukum yang berlaku. Menurut Tunggal (2010: 196) ada lima komponen pengendalian yaitu sebagai berikut:

1. Lingkungan pengendalian internal (Control environment)

2. Penilaian risiko (Risk assessment)

3. Aktivitas pengendalian (Control activities)

4. Informasi dan komunikasi (Information and communication)

5. Pemantauan (Monitoring)

\section{Whistleblowing System}

Gottschalk (2011, vol 3:1) menyatakan whistleblowing adalah pengungkapan oleh anggota organisasi (atau mantan) atas suatu praktik ilegal, tidak bermoral, atau praktikpraktik tidak sah di bawah kendali pemberi kerja mereka, kepada orang-orang atau organisasi yang mungkin dapat memengaruhi tindakan. Jadi dari definisi ini dapat disimpulkan bahwa whistleblowing system adalah pengungkapan yang dilakukan oleh anggota organisasi mengenai informasi atau praktik-praktik ilegal yang melanggar peraturan dan hukum. Di dalam Pedoman Whistleblowing System yang diterbitkan Komite Nasional Kebijakan Governance-KNKG (2008: 9), sistem whistleblowing terdiri dari tiga aspek, yaitu:
a) Aspek struktural
b) Aspek operasional
c) Aspek perawatan

\section{Good Corporate Governance}

Sutedi (2011: 1) mengemukakan pengertian good corporate governance secara definitif adalah: "Sistem yang mengatur dan mengendalikan perusahaan untuk menciptakan nilai tambah (value added) untuk semua stakeholder". Menurut Komite Nasional Kebijakan Governance-KNKG (2006: 5) ada lima aspek dalam prinsipprinsip GCG, yaitu:

1. Transparansi

2. Akuntabilitas

3. Responsibilitas

4. Independensi 


\section{Kewajaran dan Kesetaraan}

\section{Pencegahan Fraud}

Tunggal (2012: 2) berpendapat bahwa kecurangan (fraud) adalah penipuan yang disengaja, umumnya diterangkan sebagai kebohongan, penjiplakan dan pencurian. Kecurangan semacam ini menunjukkan adanya keinginan yang disengaja, tidak termasuk ketidaktahuan. Dengan demikian dapat disimpulkan bahwa fraud adalah berbagai macam cara kecerdikan manusia yang direncanakan dan dilakukan secara individual maupun berkelompok yang dilakukan dengan sengaja oleh pelakunya untuk keuntungan pribadi dan atau keuntungan organisasi yang dilakukan dengan melanggar ketentuan yang berlaku dengan cara menyembunyikan dalam atau melalui rekayasa yang tidak benar sehingga menimbulkan kerugian bagi pihak lain.

\section{Karakteristik Fraud}

Fraud selalu dikaitkan korupsi, padahal karakteristik atau jenis-jenis fraud itu sendiri banyak tidak hanya korupsi saja. ACFE dalam Tuanakotta (2010: 97) membagi fraud (kecurangan) menjadi tiga jenis berdasarkan perbuatan dan dikenal dengan fraud tree. Occupational fraud tree memiliki tiga cabang utama yaitu corruption, asset misappropiation, dan fraudulent statement.

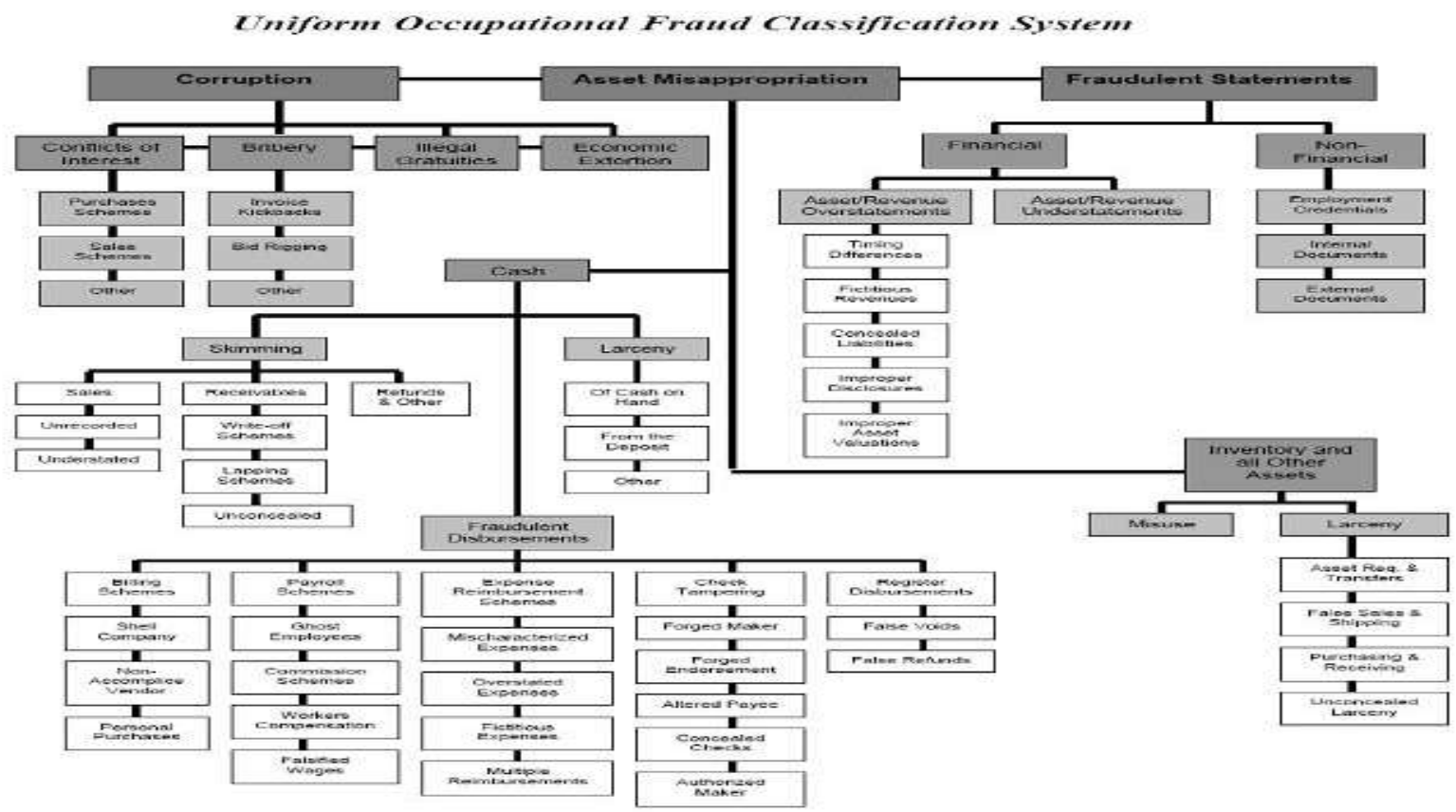

Gambar 2. The Fraud Tree

Sumber: Association of Certified Fraud Examiners (ACFE) Manual, 2007

\section{Pencegahan Fraud}

Menurut Committee of Sponsoring Organizations-COSO (1992) pencegahan kecurangan pada umumnya adalah aktivitas yang dilaksanakan manajemen dalam hal penetapan kebijakan, sistem dan prosedur yang membantu meyakinkan bahwa tindakan yang diperlukan sudah dilakukan dewan komisaris, manajemen, dan personil lain perusahaan untuk dapat memberikan keyakinan memadai dalam mencapai tiga tujuan pokok yaitu: keandalan pelaporan keuangan, efektivitas dan efisiensi operasi serta kepatuhan terhadap hukum dan peraturan yang berlaku. Sedangkan menurut Pusdiklatwas BPKP (2008: 37) pencegahan 
fraud adalah upaya yang terintegrasi yang dapat menekan terjadinya faktor penyebab fraud (fraud triangle) yaitu:

1. Memperkecil peluang terjadinya kesempatan untuk berbuat kecurangan.

2. Menurunkan tekanan kepada pegawai agar ia mampu memenuhi kebutuhannya.

3. Mengeliminasi alasan untuk membuat pembenaran/rasionalisasi atas tindak kecurangan yang dilakukan.

Pope (2007: 388) menyatakan bahwa pencegahan fraud dalam hal pengadaan barang publik, terdiri dari:

1. Memperkuat kerangka hukum.

2. Prosedur transparan.

3. Membuka dokumen tender.

4. Evaluasi penawaran.

5. Melimpahkan wewenang.

6. Pemeriksaan dan audit independen.

\section{Kerangka Pemikiran}

Hubungan Pengendalian Internal dengan Pencegahan Fraud

Hubungan antara pengendalian internal dengan masalah kecurangan dalam perusahaan sangat erat kaitannya. Pengendalian internal dalam suatu perusahaan dipercaya dapat bermanfaat dalam membantu perusahaan untuk mencegah terjadinya fraud. Menurut Tuanakotta (2007: 162) upaya mencegah fraud dimulai dari pengendalian intern. Disamping pengendaian internal, dua konsep penting dalam pencegahan fraud yaitu menanamkan kesadaran tentang adanya fraud (fraud awareness) dan upaya menilai resiko terjadinya fraud (fraud risk assessment). Dari pengertian ini dapat disimpulkan bahwa fraud dapat dikurangi bahkan dicegah dengan membudayakan kejujuran, keterbukaan, dan saling membantu satu sama lain serta menghilangkan peluang seseorang untuk melakukan fraud dengan menanamkan kesadaran tentang adanya fraud dan sangsi atas perbuatan tersebut.

\section{Hubungan Whistleblowing System dengan Pencegahan Fraud}

Widyantari (2013) menyatakan bahwa efektivitas sistem whistleblowing membantu perusahaan keluar dari kecurangan yang terjadi dalam perusahaan dan membantu perusahaan agar mampu mencapai tujuan yang telah direncanakan perusahaan dengan cara yang bersih. Pendapat Priantara (2013) menyebutkan bahwa salah satu sistem yang digunakan dalam mencegah terjadinya kecurangan adalah dengan menerapkan sistem pelaporan dugaan fraud (whistleblower hotlines). Di Amerika sistem whistleblower hotlines ini diwajibkan karena menurut berbagai survei di sana, sistem ini menjadi alat yang paling utama untuk mencegah dan mendeteksi kecurangan karena calon pelaku pastinya akan merasa takut bila diadukan.

Penelitian yang dilakukan oleh Irvandly (2014) menunjukkan bahwa penerapan whistleblowing system berpengaruh signifikan terhadap pencegahan kecurangan. Kemudian besar pengaruh penerapan whistleblowing system dalam memberikan kontribusi pengaruh terhadap pencegahan kecurangan adalah sebesar $16,3 \%$. Jadi semakin baik penerapan whistleblowing system di dalam perusahaan, maka semakin tinggi tingkat pencegahan kecurangan. Dari beberapa hasil penelitian tersebut dapat disimpulkan bahwa whistleblowing system dapat mencegah terjadinya fraud karena sistem ini dapat dengan cepat mendeteksi adanya fraud sehingga dapat langsung ditindaklanjuti laporan yang telah disampaikan oleh whistleblower.

\section{Hubungan Good Corporate Governance dengan Pencegahan Fraud}

Struktur corporate governance mengenal dua mekanisme tata kelola yaitu tata kelola internal dan tata kelola eksternal. Masing-masing tata kelola internal dan eksternal mempunyai elemen-elemen yang kalau semua elemen tata kelola eksternal dan 
internal tersebut dapat berfungsi dengan baik, maka fraud dapat dicegah atau dikurangi.

Menurut Gusnardi (2011) dalam penelitiannya menyatakan bahwa komite audit, pengendalian internal, audit internal, dan pelaksanaan tata kelola perusahaan yang baik akan berpengaruh signifikan terhadap pencegahan kecurangan perusahaan. Beawiharta (2014) juga mengatakan bahwa implementasi good government governance berpengaruh signifikan positif terhadap pencegahan kecurangan karena semakin tinggi implementasi good government governance, maka tindakan pencegahan kecurangan akan semakin meningkat. Menurut Aprijana (2014) bahwa dengan menerapkan good governance dan meningkatkan keahlian yang lebih profesional dalam pengawasan dan pemeriksaan mengenai penyajian laporan keuangan, maka akan mampu melakukan pencegahan dan pendeteksian suatu kecurangan serta menciptakan keberhasilan tujuan organisasi. Dengan tercapainya tujuan organisasi, maka terbuka menuju terwujudnya pemerintahan yang bersih dan akuntabel, sehingga akan memberikan dampak positif bagi tujuan kesejahteraan masyarakat.

Jadi dapat disimpulkan bahwa good corporate governannce dapat mencegah atau mengurangi fraud sehingga perlu adanya pemahaman tentang struktur, mekanisme, prinsip dan fungsi corporate governance yang harus dijalankan secara bersamaan. Penjelasan mengenai pengaruh pengendalian internal, whistleblowing system, peran good corporate governance terhadap pencegahan fraud dapat dilihat melalui paradigma penelitian berikut ini.

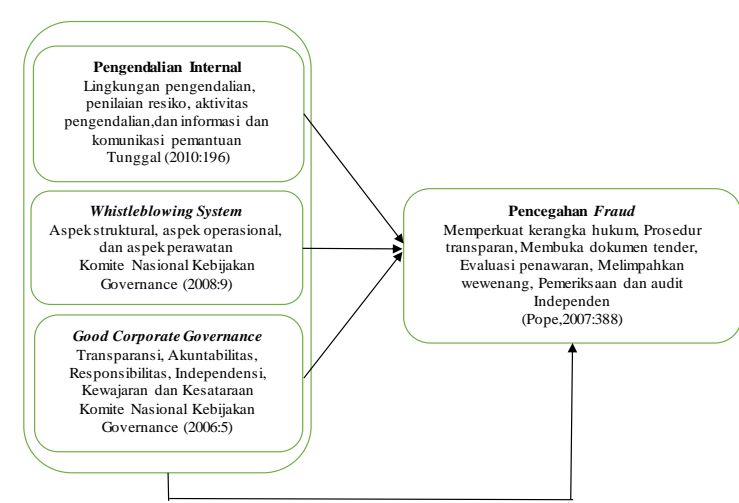

Gambar 3. Paradigma Penelitian

\section{Pengembangan Hipotesis}

Dari kerangka pemikiran di atas, maka disusun beberapa hipotesis penelitian sebagai berikut:

$\mathrm{H} 1$ : Pengendalian internal berpengaruh terhadap pencegahan fraud.

$\mathrm{H} 2$ : Whistleblowing system berpengaruh terhadap pencegahan fraud.

H3: Good corporate governance berpengaruh terhadap pencegahan fraud.

$\mathrm{H} 4$ : Pengendalian internal, whistleblowing system, dan good corporate governance berpengaruh terhadap pencegahan fraud.

\section{METODE PENELITIAN}

Penelitian yang dilakukan dalam penelitian ini adalah penelitian kausatif., Metode penelitian yang dilakukan adalah metode survei dengan menggunakan kuesioner kepada responden. Jenis pengukuran variabel yang digunakan dalam penelitian ini adalah ukuran ordinal. Ukuran yang digunakan untuk menilai jawabanjawaban dalam menguji variabel independen yaitu lima tingkatan.

Tabel 1. Skor Skala Likert

\begin{tabular}{|c|l|}
\hline Skor & \multicolumn{1}{|c|}{ Jawaban } \\
\hline 1 & Sangat Tidak Setuju (STS) \\
\hline 2 & Tidak Setuju (TS) \\
\hline 3 & Netral (N) \\
\hline 4 & Setuju (S) \\
\hline 5 & Sangat Setuju (SS) \\
\hline
\end{tabular}



digunakan dalam penelitian ini dapat dilihat pada tabel di bawah ini:

Tabel 2. Operasionalisasi Variabel

\begin{tabular}{|c|c|c|c|c|}
\hline Variabel & Konsep Variabel & Indikator & Kuesioner No & Skala \\
\hline \multirow[t]{2}{*}{ Pengendalian Internal (X1) } & Tunggal(2010:195) & $\mid$ Tunggal(2010:196) & & Ordinal \\
\hline & $\begin{array}{l}\text { Suatu proses yang dijalankan } \\
\text { oleh Dewan Komisaris, } \\
\text { Manajemen, dan Personal } \\
\text { entitas lain yang di desain untuk } \\
\text { memberikan keyakinan memadai } \\
\text { tentang pencapaian tiga } \\
\text { golongan tujuan berikut ini :(a) } \\
\text { Keandalan pelaporan keuangan } \\
\text { (b) Efektivitas dan efisiensi } \\
\text { operasi, dan (c) Kepatuhan } \\
\text { terhadap hukum. }\end{array}$ & $\begin{array}{l}\text { - Lingkungan pengendalian, } \\
\text { - Penilaian resiko, } \\
\text { - Aktivitas pengendalian, } \\
\text { - Informasi dan komunikasi, } \\
\text { - Pemantauan }\end{array}$ & $\begin{array}{l}1,2,3,4,5,67,8,9,10,11 \\
12,13,14 \\
15,16 \\
17,18,19 \\
20,21\end{array}$ & \\
\hline \multirow[t]{2}{*}{ Whistleblowing System (X2) } & Elias (2008:283) & KNKG(2008:9) & & Ordinal \\
\hline & $\begin{array}{l}\text { Pelaporan oleh anggota dari } \\
\text { suatu organis asi (sekarang atau } \\
\text { terdahulu) terhadap praktek } \\
\text { ilegal, imoral, dan haram yang } \\
\text { berada dibawah kontrol } \\
\text { karyawan terhadap orang atau } \\
\text { organis asi yang mungkin dapat } \\
\text { mengakibatkan suatu tindakan. }\end{array}$ & $\begin{array}{l}\text { - Aspek struktural, } \\
\text { - Aspek operasional, } \\
\text { - Aspek perawatan }\end{array}$ & $\begin{array}{l}22,23,24,25,26,27 \\
28,29,30 \\
31,32,33\end{array}$ & \\
\hline \multirow{2}{*}{$\begin{array}{l}\text { Good Corporate Governance } \\
\text { (X3) }\end{array}$} & Sutedi(2011:1) & KNKG(2006:5) & & Ordinal \\
\hline & $\begin{array}{l}\text { Sistem yang mengatur dan } \\
\text { mengendalikan perusahaan } \\
\text { untuk menciptakan nilai tambah } \\
\text { (value added) untuk semua } \\
\text { stakeholder. }\end{array}$ & $\begin{array}{l}\text { - Transparansi } \\
\text { - Akuntabilitas } \\
\text { - Responsibilitas } \\
\text { - Independensi } \\
\text { - Kewajaran dan Kesataraan }\end{array}$ & \begin{tabular}{|l}
$34,35,36$ \\
37 \\
38 \\
39 \\
40 \\
\end{tabular} & \\
\hline \multirow[t]{2}{*}{ Pencegahan Fraud (Y) } & Tuanakotta(2007:168) & Pope(2007:388) & & Ordinal \\
\hline & $\begin{array}{l}\text { A system of "special purpose" } \\
\text { processes and procedures } \\
\text { designed and practiced for the } \\
\text { primary if not sole purpose of } \\
\text { preventing or deterring fraud }\end{array}$ & $\begin{array}{l}\text { - Memperkuat kerangka hukum } \\
\text { - Prosedur transparan } \\
\text { - Membuka dokumen tender } \\
\text { - Evaluasi penawaran } \\
\text { - Melimpahkan Wewenang } \\
\text { - Pemeriksaan dan audit } \\
\text { Independen }\end{array}$ & $\begin{array}{l}41,42 \\
43,44,45 \\
46 \\
47 \\
48 \\
49\end{array}$ & \\
\hline
\end{tabular}

Data yang dikumpulkan dalam penelitian ini adalah data primer yang merupakan kuesioner, yaitu daftar pertanyaan tertulis yang sudah dirumuskan sebelumnya untuk responden memberikan jawaban mereka. Tehnik pengumpulan data yang digunakan dalam penelitian ini antara lain:

1. Penelitian Lapangan (Field Reserach)
a. Metode Wawancara
b. Metode Angket/Kuesioner

2. Studi Pustaka

Populasi dalam penelitian ini adalah pegawai unit Direktorat Jenderal Pengelolaan Ruang Laut Kementerian Kelautan dan Perikanan. Penelitian ini menggunakan metode purposive sampling. Sampel terdiri dari anggota kelompok kerja Unit Layanan Pengadaan (ULP) dan anggota Layanan Pengadaan Secara Elektronik (LPSE ) yang berjumlah 53 orang.

\section{Uji Validitas dan Reliabilitas}

Uji validitas adalah untuk mengukur sah atau valid tidaknya suatu kuesioner. Dalam penentuan layak atau tidaknya suatu item yang digunakan, dilakukan uji signifikansi koefisien korelasi pada taraf signifikansi 0,05 , artinya suatu item dianggap valid jika berkorelasi signifikan terhadap skor totalnya. Koefisien korelasi item-total dengan bivariate pearson dapat dicari dengan menggunakan rumus berikut:

$$
\text { rix }=\frac{n \sum i x-\left(\sum i\right)\left(\sum x\right)}{\sqrt{n \sum i^{2}-\left(\sum i\right)^{2}\left(n \sum x^{2}-\left(\sum x\right)^{2}\right]}}
$$

\section{Keterangan:}

rix $=$ Koefisien korelasi item-total (bivariate pearson)

$\mathrm{i}=$ Skor item

$\mathrm{x}=$ Skor total 
n = Banyaknya subyek

Jika $r$ hitung $\geq r$ tabel maka instrumen atau item-item pertanyaan berkorelasi signifikan terhadap total skor, sehingga dinyatakan valid. Jika $r$ hitung $<r$ tabel maka instrumen atau item-item pertanyaan berkorelasi signifikan terhadap total skor, maka dinyatakan tidak valid.

Uji reliabilitas dimaksudkan untuk mengetahui konsistensi alat ukur dalam penggunaannya, atau dengan kata lain alat ukur tersebut mempunyai hasil yang konsisten apabila digunakan berkali-kali dalam waktu yang berbeda. Untuk uji reliabilitas ini akan digunakan metode alpha cronbach. Menurut Gendro (2011: 126), suatu instrumen dikatakan handal bila memiliki koefisien cronbach alpha lebih dari 0,60 .

$r=\alpha=\left(\frac{N}{N-1}\right)\left(\frac{S^{2}-\sum S_{i}^{2}}{S^{2}}\right)$ $r=\alpha=$ Reliabilitas internal seluruh instrumen

$\mathrm{N}=$ Jumlah item kuesioner

$S^{2}=$ Varian dari total skor variabel

$S_{i}^{2}=$ Varian dari skor item ke-i

\section{Metode Analisis}

Metode yang digunakan untuk menganalisis pada penelitian ini adalah analisis regresi berganda. Model regresi yang digunakan dirumuskan:

$$
Y=a B^{1} X^{1}+B^{2} X^{2}+B^{3} X^{3}+\varepsilon
$$

Keterangan:

$Y=$ Pencegahan Fraud

$\mathrm{X}_{1}=$ Pengendalian Internal

$\mathrm{X}_{2}=$ Whistleblowing System

$\mathrm{X}_{3}=$ Good Corporate Governance

$\varepsilon=$ Variabel lain yang tidak diteliti tapi berpengaruh (contoh: Peran Audit Internal dan Budaya Etis)

Keterangan:

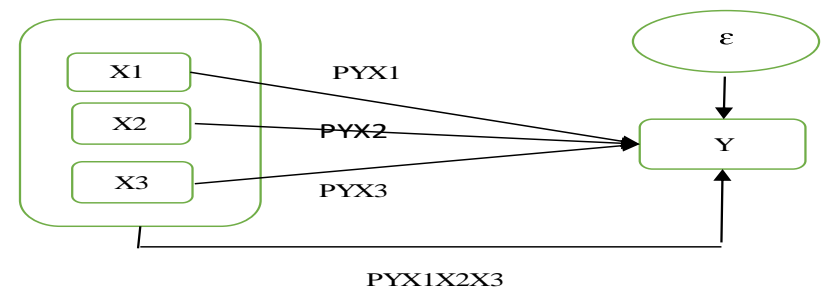

Gambar 4. Desain Penelitian

Keterangan:

PYX $_{1} \quad=$ Variabel $X_{1}$ berpengaruh parsial terhadap variabel $Y$

$\mathrm{PYX}_{2} \quad=$ Variabel $\mathrm{X}_{\mathbf{2}}$ berpengaruh parsial terhadap variabel $Y$

$\mathrm{PYX}_{3} \quad=$ Variabel $\mathrm{X}_{3}$ berpengaruh parsial terhadap variabel $Y$

$\mathrm{PY}_{1} \mathrm{X}_{2} \mathrm{X}_{3}=$ Variabel $\mathrm{X}_{1} \mathrm{X}_{2} \mathrm{X}_{3}$ berpengaruh simultan terhadap variabel $Y$ $\varepsilon \quad=$ Variabel lain yang tidak diteliti tapi berpengaruh (contoh: Peran Audit Internal dan Budaya Etis)

\section{Pengujian Hipotesis}

Uji t, Uji F, dan Uji Determinasi $\left(R^{2}\right)$

Uji $\mathrm{t}$ digunakan untuk mengetahui kemampuan masing-masing variabel independen secara individu (partial) dalam menjelaskan perilaku variabel dependen. Jika nilai signifikansi kurang atau sama dengan 
0,05 maka hipotesis diterima yang berarti secara parsial variabel pengendalian internal, whistleblowing system, moralitas, dan peran sistem e-proc berpengaruh terhadap pencegahan kecurangan. Sebaliknya jika nilai signifikansi lebih dari 0,05 maka hipotesis ditolak atau secara parsial variabel pengendalian internal, whistleblowing system, moralitas, dan peran sistem e-proc tidak berpengaruh terhadap pencegahan fraud.

Jika $\mathrm{t}$ penelitian > t tabel, maka $\mathrm{HO}$ ditolak dan $\mathrm{H} 1$ diterima

Jika $\mathrm{t}$ penelitian < $\mathrm{t}$ tabel, maka $\mathrm{HO}$ diterima dan $\mathrm{H} 1$ ditolak

Rumus Uji $F$ seperti yang dikemukakan oleh Sugiyono (2003: 47) sebagai berikut:

$$
\frac{R^{2}(N-m-2)}{m\left(2-R^{2}\right)}
$$

Keterangan:
$\mathrm{N}=$ banyak sampel

$\mathrm{m}=$ banyak prediktor

$\mathrm{R}=$ koefisien korelasi antara kriterium dengan prediktor.

Uji determinasi $\left(R^{2}\right)$. Pengujian $R^{2}$ digunakan untuk mengukur proporsi atau persentase sumbangan variabel independen yang diteliti terhadap variasi naik turunnya variabel dependen. $R^{2}$ berkisar antara 0 sampai $1\left(0 \leq R^{2} \leq 1\right)$. Apabila $R^{2}$ sama dengan 0 , hal ini menunjukkan bahwa tidak adanya pengaruh variabel independen terhadap variabel dependen, dan bila $\mathrm{R}^{\mathbf{2}}$ semakin kecil mendekati 0 , maka dapat dikatakan bahwa pengaruh variabel independen semakin kecil terhadap variabel dependen. Apabila $\mathrm{R}^{2}$ semakin besar mendekati 1, hal in menunjukkan semakin kuatnya pengaruh variabel independen terhadap variabel dependen.

HASIL PENELITIAN DAN PEMBAHASAN

Tabel 3. Hasil Uji Validitas Kuesioner Penelitian

\begin{tabular}{|c|c|c|c|c|}
\hline $\begin{array}{l}\text { Butir } \\
\text { Pernyataan }\end{array}$ & $\begin{array}{l}\text { Pengendalian } \\
\text { internal }\end{array}$ & $\begin{array}{l}\text { Whistleblowing } \\
\text { system }\end{array}$ & $\begin{array}{l}\text { Good } \\
\text { governance }\end{array}$ & $\begin{array}{l}\text { Pencegahan } \\
\text { fraud }\end{array}$ \\
\hline Item 1 & 0,342 & 0,554 & 0,747 & 0,660 \\
\hline Item 2 & 0,420 & 0,674 & 0,742 & 0,783 \\
\hline Item 3 & 0,485 & 0,352 & 0,747 & 0,740 \\
\hline Item 4 & 0,504 & 0,567 & 0,485 & 0,600 \\
\hline Item 5 & 0,443 & 0,732 & 0,662 & 0,666 \\
\hline Item 6 & 0,390 & 0,519 & 0,423 & 0,808 \\
\hline Item 7 & 0,450 & 0,315 & 0,376 & 0,780 \\
\hline Item 8 & 0,751 & 0,556 & & 0,431 \\
\hline Item 9 & 0,610 & 0,682 & & 0,449 \\
\hline Item 10 & 0,660 & 0,789 & & \\
\hline Item 11 & 0,539 & 0,475 & & \\
\hline Item 12 & 0,595 & 0,619 & & \\
\hline Item 13 & 0,656 & & & \\
\hline Item 14 & 0,662 & & & \\
\hline Item 15 & 0,588 & & & \\
\hline Item 16 & 0,477 & & & \\
\hline Item 17 & 0,635 & & & \\
\hline Item 18 & 0,599 & & & \\
\hline Item 19 & 0,595 & & & \\
\hline Item 20 & 0,553 & & & \\
\hline Item 21 & 0,570 & & & \\
\hline
\end{tabular}

Sumber: Lampiran Output Uji Validitas \& Reliabilitas

JIAFE (Jurnal Ilmiah Akuntansi Fakultas Ekonomi) Volume 3 No. 2 Tahun 2017, Hal. 43-60 
Pada Tabel 3. dapat dilihat bahwa nilai koefisien korelasi (indeks validitas) dari setiap butir pernyataan lebih besar dari nilai kritis 0,30 . Hasil pengujian ini menunjukkan bahwa semua butir pernyataan untuk keempat variabel penelitian valid dan layak sebagai alat ukur penelitian serta dapat digunakan untuk analisis selanjutnya.

Tabel 4. Hasil Uji Reliabilitas Kuesioner

\begin{tabular}{|l|l|l|}
\multicolumn{1}{l}{ Penelitian } \\
\hline Kuesioner & Koefisien Reliabilitas & Keterangan \\
\hline Pengendalian internal & 0,912 & reliabel \\
\hline Whistleblowing system & 0,866 & reliabel \\
\hline Good governance & 0,827 & reliabel \\
\hline Pencegahan fraud & 0,879 & reliabel \\
\hline
\end{tabular}

Sumber: Lampiran Output Uji

Validitas \& Reliabilitas

Pada Tabel 4. di atas dapat dilihat nilai koefisien reliabilitas kuesioner keempat variabel penelitian lebih besar dari nilai kritis 0,70 . Hasil pengujian ini menunjukkan bahwa semua butir pernyataan yang digunakan untuk masing-masing variabel sudah reliabel sehingga dapat disimpulkan bahwa kuesioner yang digunakan untuk mengukur keempat variabel sudah memberikan hasil yang konsisten.

\section{Analisis Deskriptif Variabel Pengendalian Internal}

Grand mean skor jawaban responden mengenai pengendalian internal pada Direktorat Jenderal Pengelolaan Ruang Laut Kementerian Kelautan dan Perikanan sebesar 3,71 berada pada interval kategori "Baik" seperti ditunjukkan pada garis kontinum berikut.

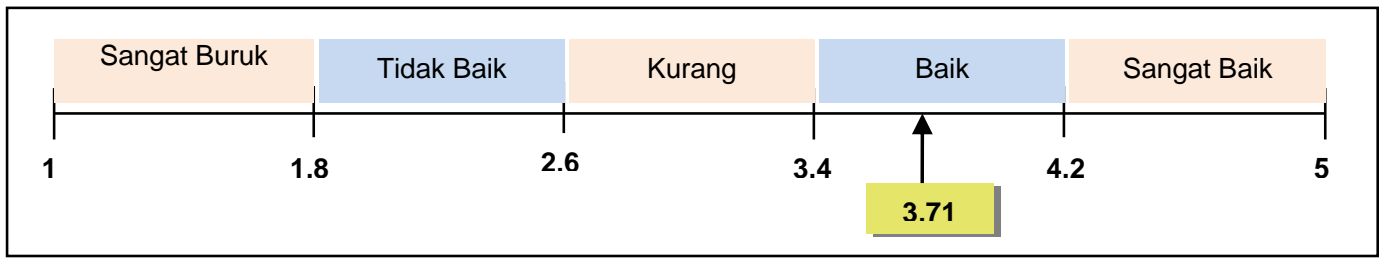

Gambar 5. Garis Kontinum Kategorisasi Variabel Pengendalian Internal

\section{Analisis Deskriptif Variabel Whistleblowing System}

Grand mean skor jawaban responden mengenai penerapan whistleblowing system pada Direktorat Jenderal Pengelolaan Ruang
Laut Kementerian Kelautan dan Perikanan sebesar 3,86 berada pada interval kategori "Baik" seperti ditunjukkan pada garis kontinum berikut.

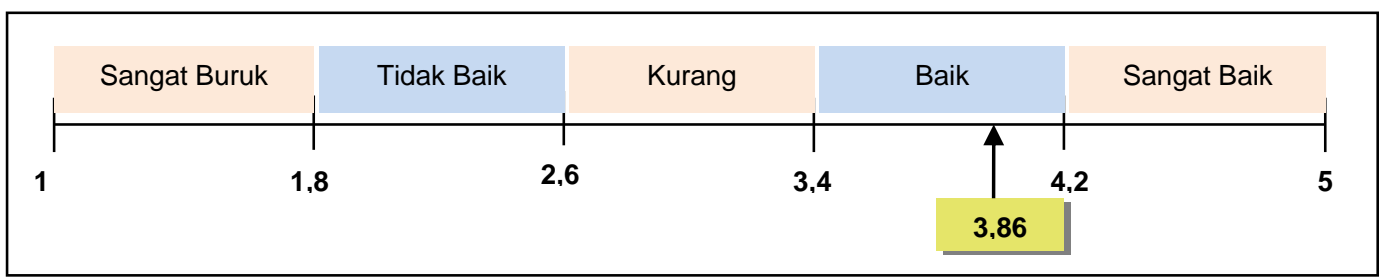

Gambar 6. Garis Kontinum Kategorisasi Variabel Whistleblowing System

$\begin{array}{llrl}\text { Analisis Deskriptif } & \text { Variabel Good } & \begin{array}{r}\text { Grand mean skor jawaban responden } \\ \text { Governance }\end{array} & \begin{array}{r}\text { mengenai penerapan good governance pada } \\ \text { Direktorat Jenderal Pengelolaan Ruang Laut }\end{array}\end{array}$


Kementerian Kelautan dan Perikanan sebesar 4,31 juga berada pada interval kategori
"Sangat Baik" seperti ditunjukkan pada garis kontinum berikut.

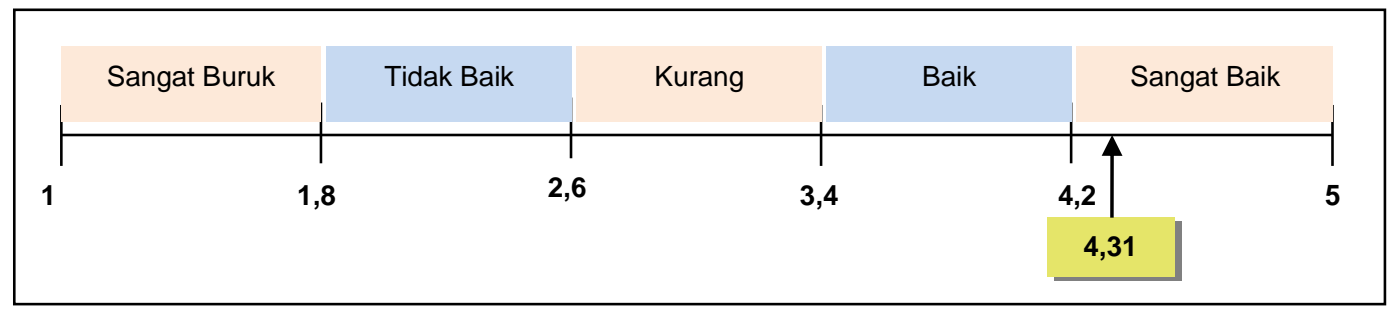

Gambar 7. Garis Kontinum Kategorisasi Variabel Good Governance

\section{Analisis Deskriptif Variabel Pencegahan} Fraud

Grand mean skor jawaban responden mengenai pencegahan fraud pada Direktorat Jenderal Pengelolaan Ruang Laut
Kementerian Kelautan dan Perikanan sebesar 4,42 berada pada interval kategori "Sangat Baik" seperti ditunjukkan pada garis kontinum berikut.

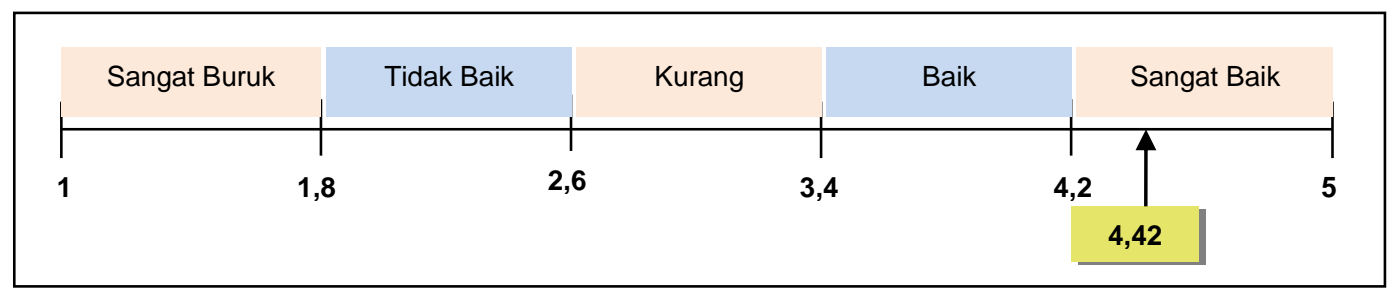

Gambar 8. Garis Kontinum Kategorisasi Variabel Pencegahan Fraud

\section{Analisis Verifikatif Uji Asumsi Klasik}

Semua tahapan pengujian dilakukan dengan bantuan Software SPSS IBM Statistics 20. Dan diketahui bahwa data yang akan diuji berdistribusi normal dan tidak ada multikolinearitas sehingga layak untuk diuji.

Tabel 5. Hasil Pengujian Asumsi Normalitas One-Sample Kolmogorov-Smirnov Test

\begin{tabular}{|ll|l|}
\hline \multicolumn{1}{|c|}{} & & $\begin{array}{l}\text { Unstandardize } \\
\text { d Residual }\end{array}$ \\
\hline N & & 53 \\
Normal Parameters ${ }^{\mathrm{a}, \mathrm{b}}$ & Mean & $0 \mathrm{E}-7$ \\
& Std. Deviation &, 26772411 \\
& Absolute &, 103 \\
Most Extreme Differences & Positive &, 103 \\
& Negative &,- 062 \\
Kolmogorov-Smirnov Z & &, 749 \\
Asymp. Sig. (2-tailed) & &, 629 \\
\hline
\end{tabular}

a. Test distribution is Normal.

b. Calculated from data.

Tabel 6. Hasil Pengujian Asumsi Multikolinieritas

Coefficients $^{\mathrm{a}}$

\begin{tabular}{|ll|l|l|}
\hline \multirow{2}{*}{ Model } & \multicolumn{2}{|l|}{ Collinearity Statistics } \\
\cline { 2 - 3 } & Tolerance & VIF \\
\hline 1 & Pengendalian Internal &, 927 & 1,079 \\
& Whistleblowing System &, 841 & 1,189 \\
& Good Governance &, 854 & 1,171 \\
\hline
\end{tabular}

a. Dependent Variable: Pencegahan Fraud

\section{Analisis Regresi Linier Berganda}

Berikut hasil perhitungan dengan menggunakan metode analisis regresi berganda. 
Tabel 7. Hasil Estimasi Persamaan Regresi

Coefficients $^{\mathrm{a}}$

\begin{tabular}{|ll|l|l|l|l|l|}
\hline Model & \multicolumn{2}{|l|}{$\begin{array}{l}\text { Unstandardized } \\
\text { Coefficients }\end{array}$} & $\begin{array}{l}\text { Standard } \\
\text { ized } \\
\text { Coefficie } \\
\text { nts }\end{array}$ & Sig. \\
\cline { 2 - 5 } & \multicolumn{2}{|l|}{ B } & Std. Error & Beta & & \\
\hline 1 & (Constant) &, 309 &, 520 & &, 593 &, 556 \\
& Pengendalian Internal &, 267 &, 090 &, 293 & 2,980 &, 004 \\
& Whistleblowing System &, 209 &, 093 &, 232 & 2,245 &, 029 \\
& Good Governance &, 537 &, 111 &, 497 & 4,856 &, 000 \\
\hline
\end{tabular}

a. Dependent Variable: Pencegahan Fraud

Melalui hasil pengolahan data seperti diuraikan pada tabel 4.29 maka dapat dibentuk model prediksi variabel pengendalian internal, whistleblowing system dan good governance terhadap pencegahan fraud sebagai berikut.

$$
\hat{\mathbf{Y}}=\mathbf{0 , 3 0 9}+\mathbf{0 , 2 6 7} \mathbf{X}_{\mathbf{1}}+\mathbf{0 , 2 0 9} \mathbf{X}_{\mathbf{2}}+\mathbf{0 , 5 3 7} \mathrm{X}_{3}^{g o v e r n a n c e} \text { akan meningkatkan pencegahan }
$$

Pada persamaan tersebut dapat fraud.

\section{Analisis Koefisien Determinasi}

bertanda positif menunjukkan bahwa semakin baik pengendalian internal akan meningkatkan pencegahan fraud. Demikian juga koefisien whistleblowing system dan good governance bertanda positif menunjukkan bahwa semakin baik whistleblowing system maupun good
Analisis Koefisien Determinasi

dilihat koefisien pengendalian internal

Tabel 8. Koefisien Determinasi

Model Summary

\begin{tabular}{l|l|l|l|l|}
\hline Model & R & R Square & Adjusted R Square & $\begin{array}{l}\text { Std. Error of the } \\
\text { Estimate }\end{array}$ \\
\hline 1 & ,749a &, 562 &, 535 &, 27580 \\
\hline
\end{tabular}
a. Predictors: (Constant), Good Governance, Pengendalian Internal, Whistleblowing System
b. Dependent Variable: Pencegahan Fraud

Nilai R sebesar 0,749 pada tabel 4.30 menunjukkan kekuatan hubungan ketiga variabel independen (pengendalian internal, whistleblowing system dan good governance) secara simultan dengan pencegahan fraud. Jadi pada permasalahan yang sedang diteliti diketahui bahwa secara simultan ketiga variabel independen (pengendalian internal, whistleblowing system dan good governance) memiliki hubungan yang kuat dengan pencegahan fraud pada Direktorat Jenderal
Pengelolaan Ruang Laut Kementerian Kelautan dan Perikanan.

Kemudian nilai R-Square sebesar 0,562 atau 56,2 persen, menunjukkan bahwa ketiga variabel independen secara simultan mampu menerangkan pencegahan fraud sebesar 56,2 persen. Artinya secara bersamasama pengendalian internal, whistleblowing system dan good governance memberikan pengaruh atau kontribusi sebesar 56,2\% terhadap pencegahan fraud pada Direktorat Jenderal Pengelolaan Ruang Laut 
Kementerian Kelautan dan Perikanan. Sisanya pengaruh faktor-faktor lain yang tidak diamati adalah sebesar 43,8\%, yaitu merupakan pengaruh faktor lain diluar ketiga variabel independen yang diteliti seperti Budaya Etis Organisasi dan Peran Audit Internal.

\section{Pengujian Hipotesis}

Selanjutnya untuk menguji apakah pengendalian internal, whistleblowing system dan good governance berpengaruh terhadap pencegahan fraud, baik secara bersama-sama maupun secara parsial maka dilakukan pengujian hipotesis. Pada pengujian secara parsial apabila nilai $\mathrm{t}$ variabel yang sedang diuji lebih besar dari $t_{\text {tabel, maka Ho ditolak }}$ dan sebaliknya apabila nilai $\mathrm{t}$ variabel yang sedang diuji lebih kecil dari $t_{\text {tabel }}$ maka Ho diterima. Pada pengujian simultan apabila ada nilai $F$ lebih besar dari $F_{\text {tabel, maka Ho }}$ ditolak dan sebaliknya apabila nilai $F$ lebih kecil dari $F_{\text {tabel, }}$ maka Ho diterima.

Tabel 9. Ringkasan uji pengaruh pengendalian internal terhadap pencegahan fraud

\begin{tabular}{|l|l|l|l|l|l|}
\hline Koefisien regresi & thitung & Sig. & tabel (db:49) $_{\text {Ho }}$ & Ha \\
\hline 0,267 & 2,98 & 0,002 & 2,01 & ditolak & diterima \\
\hline
\end{tabular}

Tabel 10. Ringkasan uji pengaruh whistleblowing system terhadap pencegahan fraud

\begin{tabular}{|l|l|l|l|l|l|}
\hline Koefisien regresi & $\mathbf{t}_{\text {hitung }}$ & Sig. & $\mathbf{t}_{\text {tabel (db:49) }}$ & Ho & Ha \\
\hline 0,09 & 2,245 & 0,029 & 2,01 & ditolak & diterima \\
\hline
\end{tabular}

Tabel 11. Ringkasan uji pengaruh good governance terhadap pencegahan fraud

\begin{tabular}{|l|l|l|l|l|l|}
\hline Koefisien regresi & $\mathbf{t}_{\text {hitung }}$ & Sig. & $\mathbf{t}_{\text {tabel (db:49) }}$ & Ho & Ha \\
\hline 0,537 & 4,856 & $<0,001$ & 2,01 & ditolak & diterima \\
\hline
\end{tabular}

Tabel 11. Tabel Pengujian Secara Simultan

ANOVA $^{\text {a }}$
\begin{tabular}{|ll|l|l|l|l|l|}
\hline Model & Sum of Squares & df & Mean Square & F & Sig. \\
\hline 1 & Regression & 4,777 & 3 & 1,592 & 20,936 &, $000^{\mathrm{b}}$ \\
& Residual & 3,727 & 49 &, 076 & & \\
& Total & 8,505 & 52 & & & \\
\hline
\end{tabular}

a. Dependent Variable: Pencegahan Fraud

b. Predictors: (Constant), Good Governance, Pengendalian Internal, Whistleblowing System

\section{Pembahasan}

\section{Pengaruh Peran Pengendalian Internal Terhadap Pencegahan Fraud}

Hasil pengujian hipotesis
menunjukkan bahwa pengendalian internal berpengaruh signifikan terhadap pencegahan fraud. Berdasarkan hasil penelitian ini diperoleh bahwa nilai t hitung lebih besar dari t tabel. Selain itu nilai koefisien regresi untuk pengendalian internal bertanda positif. Dengan demikian $\mathrm{H} 1$ terbukti atau diterima. Jadi dapat diartikan bahwa Pengendalian internal berpengaruh secara positif terhadap pencegahan fraud karena semakin baik pengendalian internal maka dapat meningkatkan pencegahan fraud. Hal ini membuktikan bahwa salah satu faktor penyebab seseorang melakukan fraud yakni adanya opportunity atau kesempatan dapat dicegah dengan adanya pengendalian internal yang baik pada suatu institusi atau organisasi.

Besarnya pengaruh peran pengendalian internal terhadap pencegahan fraud adalah $13,18 \%$ dan sisanya sebesar $86,82 \%$ dipengaruhi oleh faktor lain selain pengendalian internal seperti whisleblowing system, good governance, peran audit Internal dan budaya organisasi. Hal ini membuktikan bahwa peran pengendalian 
internal tidak dominan dalam pencegahan fraud.

\section{Pengaruh Whsitleblowing System Terhadap Pencegahan Fraud}

Hasil pengujian hipotesis kedua menunjukkan bahwa whistleblowing system berpengaruh signifikan terhadap pencegahan fraud. Berdasarkan hasil penelitian ini diperoleh bahwa nilai t hitung variabel lebih besar dari t tabel. Selain itu nilai koefisien regresi untuk variabel whistleblowing system bertanda positif. Dengan demikian $\mathrm{H} 2$ terbukti atau diterima. Jadi dapat diartikan bahwa whistleblowing system berpengaruh secara positif terhadap pencegahan fraud karena semakin baik whistleblowing system maka dapat meningkatkan pencegahan fraud. Hal ini membuktikan bahwa faktor penyebab seseorang melakukan fraud yang berasal dari faktor general yakni adanya opportunity atau kesempatan dan exposure atau pengungkapan dapat dicegah dengan adanya whistleblowing system yang efektif sehingga pelaku kecurangan jera dan berpikir kembali untuk melakukan kecurangan tersebut.

Besarnya pengaruh whistleblowing system terhadap pencegahan fraud $11,16 \%$ dan sisanya sebesar $88,84 \%$ dipengaruhi oleh faktor selain whistleblowng system. Hal ini membuktikan bahwa whistleblowing system bukan faktor dominan dalam pencegahan fraud tetapi ada faktor lain yang dominan seperti good governance, peran audit Internal dan budaya etis organisasi.

\section{Pengaruh Good Governance Terhadap Pencegahan Fraud}

Hasil pengujian hipotesis ketiga menunjukkan bahwa good governance berpengaruh signifikan terhadap pencegahan fraud. Berdasarkan hasil penelitian ini diperoleh bahwa nilai t hitung variabel lebih besar dari $t$ tabel. Selain itu nilai koefisien regresi untuk variabel good governance bertanda positif. Dengan demikian $\mathrm{H} 3$ terbukti atau diterima. Jadi dapat diartikan bahwa good governance berpengaruh secara positif terhadap pencegahan fraud karena semakin baik good governance maka dapat meningkatkan pencegahan fraud. Hal ini membuktikan bahwa faktor penyebab fraud seperti adanya opportunity dan rationalization dapat dicegah dengan adanya good governance yang baik karena setiap tindakan yang dilakukan akan dipertanggungjawabkan. Besarnya pengaruh good corporate governance terhadap pencegahan fraud 31,9\% dan sisanya sebesar $68,1 \%$ dipengaruhi oleh faktor lain selain good governance sehingga membuktikan bahwa good governance tidak dominan dalam pencegahan fraud.

\section{Pengaruh Peran Pengendalian Internal, Whistleblowing System, dan Good Governance Terhadap Pencegahan Fraud}

Hipotesis ke empat yang diajukan menunjukkan bahwa pengendalian internal, whistleblowing system dan good governance berpengaruh signifikan terhadap pencegahan fraud. Berdasarkan hasil pengolahan menggunakan software SPSS diperoleh hasil F hitung lebih besar dari $F$ tabel, maka dapat diputuskan bahwa $\mathrm{H} 4$ terbukti atau diterima. Jadi dapat disimpulkan bahwa pengendalian internal, whistleblowing system, dan good governance secara simultan berpengaruh positif terhadap pencegahan fraud. Besar pengaruh peran pengendalian internal, whistleblowing system, dan good governance terhadap pencegahan fraud sebesar 56,2\% dan sisanya sebesar $43,8 \%$ dipengaruhi oleh faktor lain.

Hasil penelitian ini menujukkan bahwa faktor pengendalian internal, whistleblowing system, dan good governance secara bersama-sama memberikan pengaruh yang positif dan signifikan terhadap pencegahan fraud. Semakin baik pengendalian internal, whistleblowing system, dan good governance maka dapat meningkatkan pencegahan fraud. 


\section{PENUTUP}

Simpulan

Berdasarkan pada hasil penelitian serta pengujian hipotesis dapat ditarik kesimpulan sebagai berikut: 1) Penerapan pengendalian internal pada Direktorat Jenderal Pengelolaan Ruang Laut Kementerian Kelautan dan Perikanan berada pada kategori baik. 2) Whistleblowing system pada Direktorat Jenderal Pengelolaan Ruang Laut Kementerian Kelautan dan Perikanan berada pada kategori baik. 3) Good corporate governance pada Direktorat Jenderal Pengelolaan Ruang Laut Kementerian Kelautan dan Perikanan berada pada kategori sangat baik. 4) Pencegahan fraud pada Direktorat Jenderal Pengelolaan Ruang Laut Kementerian Kelautan dan Perikanan berada pada kategori sangat baik, hal ini menujukkan bahwa pencegahan fraud pada institusi ini sudah dilakukan dengan sangat baik.

Peran pengendalian internal berpengaruh signifikan terhadap pencegahan fraud, hal ini terbukti bahwa hasil penelitian mendukung teori dan hasil penelitian juga membuktikan fenomena yang terjadi. Jadi dapat disimpulkan bahwa semakin baik pengendalian internal maka dapat meningkatkan pencegahan fraud. Whistleblowing system berpengaruh signifikan terhadap pencegahan fraud. Hal ini mendukung teori dan hal ini membuktikan fenomena yang terjadi ketika whistleblowing system tidak berpengaruh secara dominan. Dalam penerapan whistleblowing system maka perlu diperhatikan peran sistem pelaporan dan perlindungan bagi whistleblower sehingga akan tercipta sistem whistleblowing yang efektif, transparan dan bertanggungjawab. Jadi dapat diartikan bahwa semakin baik whistleblowing system maka dapat meningkatkan pencegahan fraud. Good governance berpengaruh signifikan terhadap pencegahan fraud. Hal ini mendukung teori dan hasil penelitian ini juga membuktikan fenomena yang terjadi. Jadi dapat disimpulkan bahwa semakin baik good governance maka dapat meningkatkan pencegahan fraud. Pengendalian internal, whistleblowing system dan good governance berpengaruh signifikan terhadap pencegahan fraud pada Direktorat Jenderal Pengelolaan Ruang Laut Kementerian Kelautan dan Perikanan. Semakin baik pengendalian internal, whistleblowing system, dan good corporate governance maka dapat meningkatkan pencegahan fraud.

\section{Keterbatasan Penelitian dan Saran}

Penelitian ini memiliki keterbatasan antara lain : 1) Berdasarkan hasil olah data penelitian yang sudah dilakukan, maka dapat diketahui bahwa sebesar $56,2 \%$ variabel independen pengendalian internal, whistleblowing system dan good governance memberikan pengaruh atau kontribusi terhadap variabel dependen pencegahan fraud dan sisanya pengaruh faktor-faktor lain diluar ketiga variabel independen yang diteliti yang tidak diamati adalah sebesar $43,8 \%$ sehingga masih banyak variabel yang cukup berpengaruh tetapi tidak dimasukkan dalam penelitian ini. 2) Jurnal ilmiah untuk membantu penelitian ini masih terbatas jumlahnya.

\section{DAFTAR PUSTAKA}

Albrecht, W.Steve, Chad O. Albrecht, 2012, Fraud Examination and Prevention, Thomson, South-Western: Australia.

Amrizal, 2004, Membangun Kultur Dan Etika Internal Organisasi Yang Anti Kecurangan.

Aprijana, A.A. Gede Rahadi. Pengaruh Pemahaman Good Governance dan Keahlian Profesional terhadap Pencegahan dan Pendeteksian Kecurangan Penyajian Laporan Keuangan (Studi Empiris pada Inspektorat Pemerintah Kabupaten Buleleng dan Inspektorat Pemerintah Kabupaten Karangasem). Skripsi, Universitas Pendidikan Ganesha 
Bastian, I, (2010), Akuntansi Sektor Publik Suatu Pengantar, Jakarata: Erlangga.

Beawiharta, Innosanto. Pengaruh Peran Inspektorat Pembantu Kota dan Implementasi Good Government Governance Terhadap Pencegahan Kecurangan pada Kota Administrasi Jakarta Timur Tahun 2014. Skripsi, Universitas Telkom.

Bologna, J, 1993, Handbook of Corporate Fraud, Butterworth-Heinemann: Boston.

CBN, 2005, Skandal Sari Husada. http://portal.cbn.net.id diakses pada 14 Februari 2016.

Committee of Sponsoring Organizations of Teadway Commission (COSO), 1992, Adendum 1994, Internal Control Integrated Framework, AICPA Publication.

COSO, 2013, Internal Control-Integrated Framework: Executive SUMMARY, Durham, North Carolina, May 2013.

Crumbley, D. Larry, Forensic and Investigative Accounting, USA : 5 Agustus 2002.

Dewi, 2015, Kerugian Negara Akibat Korupsi 2015 Sebesar 3,1 Triliun http://www.antikorupsi.org diakses pada 14 Februari 2016.

Elias, Rafik , 2008, Auditing Students' Professional Commitment and Anticipatory Socialization and Their Relationship To Whistleblowing", Managerial Auditing Journal, Vol. 23, No.3, h.283-294.

Gendro Wiyono. 2011. Merancang Penelitian Bisnis dengan alat analisis SPSS 17.0 \& SmartPLS 2.0. Yogyakarta : Unit Penerbitan dan Percetakan STIM YKPN.

Gusnardi. 2011. Pengaruh Peran Komite Audit, Pengendalian Internal, Audit Internal dan Pelayanan Tata Kelola Perusahaan Terhadap Pencegahan Kecurangan. Skripsi, Universitas Riau.

Gottschalk, Petter, 2011, Pencegahan Kejahatan Kerah Putih: Peran Akuntansi, Journal of Forensic \& Investigative Accounting Vol. 3, Issue 1.
Harahap, Aurolla Saparini, 2013, Fraud di Tempat Kerja, https://manajemenppm.wordpress.com diakses pada 14 Februari 2016.

Hartanti, Evi, 2005, Tindak Pidana Korupsi, Jakarta: Sinar Grafika.

Hermiyetti, 2010, Pengaruh Penerapan Pengendalian Internal Terhadap Pencegahan Fraud Pengadaaan Barang, Artikel STEKPI: Jakarta .

Hopwood, et al. (2008). Forensic Accounting. New York: McGraw Hill.

Institut Akuntan Publik Indonesia, 2011, Standar Profesi Akuntan Publik (SPAP), Edisi Mei 2011, Penerbit ikatan Akuntan public Indonesia: Jakarta.

Jackson. 2001. Manajemen Sumber Daya Manusia. Terjemahan oleh Jimmy Sadeli \& Bayu Prawira Hie. Jakarta: Salemba, hal : 78

James A. Hall diterjemahkan oleh Thomson Learning, 2006, Sistem Informasi Akuntansi, Edisi pertama. Salemba Empat: Jakarta.

Kimia Farma (Etika Bisnis), 2013, http://www.kompasiana.com diakses pada 14 Februari 2016.

Komite Nasional Kebijakan Governance (KNKG), 2006, Pedoman Umum Good Corporate Governance Indonesia, Jakarta.

Komite Nasional Kebijakan Governance (KNKG), 2008, Pedoman Sistem Pelaporan Pelanggaran-SPP (Whistleblowing System-WBS), Jakarta.

Krismiaji, 2010, Sistem Informasi Akuntansi, Edisi Ketiga, Yogyakarta: UPP STIM YKPN.

Lembaga Kebijakan Pengadaan Barang/Jasa Pemerintah (LKPP). 2010, Modul 1 Pelatihan Pengadaan Barang/jasa Pemerintah Tingkat Dasar/Pertama, Team LKPP. Jakarta.

Pristiyanti, I. R. (2012), Persepsi Pegawai Instansi Pemerintahan Mengenai Faktor-Faktor yang Mempengaruhi Fraud di Sektor Pemerintahan, 
Accounting Analysis Journal, ISSN 2252-6765.

Mardiasmo, 2002, Otonomi dan Manajemen Keuangan Daerah, Yogyakarta: Andi.

Maurice E. Peloubet, "Forensic Accounting: Its place in today's economy", Journal of Accountancy edisi Juni 1946,. h.34.

Nawawi, Muzakky, 2012, Korupsi Pengadaan Barang Dan Jasa, http://zqzakky.blogspot.co.id diakses pada Februari 2016.

Miceli, M. P. \& J. P. Near, (1985), Characteristics of Organizational Climate and Perceived Wrongdoing Associated with Whisde-Blowing Decisions, Personnel Psychology, 38, vol 4:1.

Pratana, Irvandly. 2014. Pengaruh Penerapan Whistleblowing System terhadap Pencegahan Kecurangan (Studi Survey pada PT.Coca Cola Amatil Indnesia SO Bandung). Skripsi, Universitas Widyatama Bandung

Priantara, Diaz, 2013, Fraud Auditing \& Investigation, Mitra Wacana Media: Jakarta.

Pope, Jeremy,2007, Strategi Memberantas Korupsi: El

Rina, 2016, Laporan Terkait Pengadaan Barang Dan Jasa, 2015, http://news.detik.com diakses pada Februari 2016.

Simanjuntak, Ridwan, 2008, Pengertian dan Pencegahan Kecurangan. Seri Departemen Akuntansi : FEUI.

Singleton, Tommie, et.al, 2006, Fraud Auditing and Forensic Accounting, John Wley and Sons, Inc: Canada.
Sutedi, Adrian, 2011, Good Corporate Governance, Jakarta: Sinar Grafika.

Sutojo, Siswanto, Aldridge, E. John, 2005, Good Corporate Governance: Tata Kelola Perusahaan Yang Sehat, Jakarta: PT. Damar Mulia Rahayu.

Tuanakotta, Theodorus M, (2007), Akuntansi Forensik dan Audit Investigatif, Lembaga Penerbitan Fakultas Ekonomi Universitas Indonesia, Salemba Empat: Jakarta.

Tuanakotta, Theodorus M, 2010, Akuntansi Forensik dan Audit Investigatif, SALEMBA Empat: Jakarta.

Tunggal, Amin Widjaja, 2010, Teori dan Praktek Auditing, Harvarindo: Jakarta.

Tunggal, Amin Widjaya, 2010, Dasar-Dasar Audit Internal Pedoman Untuk Auditor Baru. Harvarindo: Jakarta.

Sudarmo, Sawardi, \& Yulianto, A., 2008, Fraud Auditing Edisi Kelima, Pusdiklat BPKP: Jakarta.

Sinaga, Eri Komar, 2015, Ratu Atut Diperiksa Lagi untuk Kasus Korupsi Alat Kesehatan, http://www.tribunnews.com diakses pada 14 Februari 2016.

Widyantari, Arti. 2013. Pengaruh Efektivitas Sistem Whistleblowing Terhadap Upaya Pengungkapan Kecurangan Manajamen Melalui Pemberian Motivasi (studi kasus pada Dinas Pendidikan Kota Cirebon). Thesis, Universitas Pasundan.

Yenny, 2014, Makalah Studi Kasus Teori Akuntansi, http://fatmawatiyeny.blogspot.co.id Fatmawati diakses pada 14 Februari 2016. 